\title{
Phylogenetic radiation of the greenbottle flies (Diptera, Calliphoridae, Luciliinae)
}

\author{
Kirstin A. Williams ${ }^{1,2}$, Jennifer Lamb³, Martin H. Villet ${ }^{2}$ \\ I Entomology Department, Durban Natural Science Museum, Durban, South Africa 2 Southern African \\ Forensic Entomology Research Laboratory, Department of Zoology and Entomology, Rhodes University, Gra- \\ hamstown, South Africa 3 School of Life Sciences, University of KwaZulu-Natal, South Africa
}

Corresponding author: Kirstin A. Williams (Kirstin.Williams@durban.gov.za)

Academic editor: P. Cerretti | Received 29 September 2015 | Accepted 18 January 2016 | Published 23 February 2016

http://zoobank.org/1BFDEE7B-3A92-423E-9FF8-1DC9AF1EDF35

Citation: Williams KA, Lamb J,Villet MH (2016) Phylogenetic radiation of the greenbottle flies (Diptera, Calliphoridae, Luciliinae). ZooKeys 568: 59-86. doi: 10.3897/zookeys.568.6696

\begin{abstract}
The subfamily Luciliinae is diverse and geographically widespread. Its four currently recognised genera (Dyscritomyia Grimshaw, 1901, Hemipyrellia Townsend, 1918, Hypopygiopsis Townsend 1916 and Lucilia Robineau-Desvoidy, 1830) contain species that range from saprophages to obligate parasites, but their pattern of phylogenetic diversification is unclear. The $28 S$ rRNA, COI and Period genes of 14 species of Lucilia and Hemipyrellia were partially sequenced and analysed together with sequences of 11 further species from public databases. The molecular data confirmed molecular paraphyly in three species-pairs in Lucilia that hamper barcode identifications of those six species. Lucilia sericata and L. cuprina were confirmed as mutual sister species. The placements of Dyscritomyia and Hypopygiopsis were ambiguous, since both made Lucilia paraphyletic in some analyses. Recognising Hemipyrellia as a genus consistently left Lucilia s.l. paraphyletic, and the occasionally-recognised (sub)genus Phaenicia was consistently paraphyletic, so these taxa should be synonymised with Lucilia to maintain monophyly. Analysis of a matrix of 14 morphological characters scored for adults of all genera and for most of the species included in the molecular analysis confirmed several of these findings. The different degrees of parasitism were phylogenetically clustered within this genus but did not form a graded series of evolutionary stages, and there was no particular relationship between feeding habits and biogeography. Because of the ubiquity of hybridization, introgression and incomplete lineage sorting in blow flies, we recommend that using a combination of mitochondrial and nuclear markers should be a procedural standard for medico-criminal forensic identifications of insects.
\end{abstract}

\section{Keywords}

Lucilia sericata, Lucilia cuprina, molecular systematics, parasitism, myiasis

Copyright Kirstin A. Williams et al. This is an open access article distributed under the terms of the Creative Commons Attribution License (CC BY 4.0), which permits unrestricted use, distribution, and reproduction in any medium, provided the original author and source are credited. 


\section{Introduction}

All four genera of the subfamily Luciliinae are reported to exhibit parasitism in the form of myiasis - the infestation of humans' and other animals' living tissues by fly larvae (Stevens 2003) - ranging from facultative secondary necrophagous myiasis in species like Lucilia sericata (Meigen, 1826) to obligate primary carnivorous myiasis in species such as Lucilia bufonivora Moniez, 1876. Lucilia cuprina (Wiedemann, 1830) and L. sericata are noted veterinary pests. Molecular approaches to the management of these flies' populations can be built on a phylogenetic analysis of the species, but such analyses based on morphological data (Stevens and Wall 1997, Otranto and Stevens 2002, Stevens 2003) have found no evolutionary pattern underlying the radiation of feeding behaviours in Lucilia RobineauDesvoidy, 1830, and biogeographical patterns in the different forms of myiasis have yet to be studied. Furthermore, several taxonomic questions remain regarding the subfamily, from the molecular identification of its species to the definitions of its genera.

At the highest taxonomic level, Rognes (1991) suggested that the genera Dyscritomyia Grimshaw, 1901, Hemipyrellia Townsend, 1918, Hypopygiopsis Townsend 1916, and Lucilia Robineau-Desvoidy, 1830 should be united in the subfamily Luciliinae. Several phylogenetic studies have placed species of Hemipyrellia within Lucilia (Wells et al. 2007, Park et al. 2009, Liu et al. 2011, McDonagh and Stevens 2011). Evidence of whether Dyscritomyia is related to Lucilia or nested within it has depended on which gene was analysed (Wells et al. 2007, McDonagh and Stevens 2011). The definitions and relationships of these genera therefore need attention.

Several other genera have been included in the Luciliinae, such as Bufolucilia Townsend, 1919, Francilia Shannon, 1924, Acrophagella Ringdahl, 1942, Phumonesia Villeneuve, 1914 and Viridinsula Shannon, 1926 but most of these are now treated as synonyms of Lucilia. Lucilia itself has been variously divided into subgenera (Malloch 1926) or genera (Hall 1948), respectively. Phaenicia Robineau-Desvoidy, 1863 has been the most used of these names and its use persists (e.g. Park et al. 2009) even though its validity has been challenged regularly (Aubertin 1933, Zumpt 1965, Stevens and Wall 1996). A phylogenetic study of Lucilia presents an opportunity to assess this matter.

The largest genus in the subfamily, Lucilia has received few quantitative phylogenetic studies (Aubertin 1933, Stevens and Wall 1996, 1997, Wells et al. 2007, Park et al. 2009, DeBry et al. 2012, Sonet et al. 2012), with research generally focusing on species of medical, veterinary or forensic interest in specific geographic regions (Stevens and Wall 2001, Chen et al. 2004, Wallman et al. 2005, Harvey et al. 2008, Reibe et al. 2009, Liu et al. 2011, Boehme et al. 2012, DeBry et al. 2012, Nelson et al. 2012, Sonet et al. 2013). The most comprehensive revision of the genus was published by Aubertin (1933), who recognised 27 species. Since then revisions of the genus and keys for the identification of its species have been produced, but only for specific geographic regions (Hall 1948, James 1971, Rognes 1980, 1991, Smith 1986, Whitworth 2006, 2010). Most species of Lucilia are limited to particular continents or islands and very few, such as $L$. sericata, are cosmopolitan. It is difficult to assess relationships and biogeographical patterns when studies are taxonomically geographically fragmented. 
At the species level, L. sericata and L. cuprina have been referred to as sister-species (Ash and Greenberg 1974) because they are very similar morphologically and each is often misidentified as the other. They are now both found in Australia, New Zealand, South Africa, large parts of Asia, Europe and North America (Waterhouse and Paramonov 1950, Rognes 1980, 1994, Norris 1990, Bishop 1991, 1995, Holloway 1991, Fischer 2000, Harvey et al. 2003a, 2003b, 2008, Chen et al. 2004, Heath and Bishop 2006, Park et al. 2009, Liu et al. 2011, Boehme et al. 2012, GilArriortua et al. 2013). They have each received intensive biological investigation, and it would benefit comparative studies if it could be confirmed that they are actually sister species.

Several studies have established that natural hybrids of L. sericata and L. cuprina exist (Stevens and Wall 1996, Stevens et al. 2002, Wallman et al. 2005, Tourle et al. 2009, DeBry et al. 2010, Williams and Villet 2013). Two other species pairs, Lucilia coeruleiviridis Macquart, 1855 and L. mexicana Macquart, 1843, and L. caesar (Linnaeus, 1758) and L. illustris (Meigen, 1826), also show molecular paraphyly (DeBry et al. 2012, Sonet et al. 2012, 2013), possibly due to introgressive hybridisation or incomplete lineage sorting. The frequency and phylogenetic distribution of this phenomenon in the genus is of general interest because of its implications for understanding speciation and diversification in the group.

The aims of this study are therefore to confirm if L. sericata and L. cuprina are sister-species; to explore if L. coeruleiviridis (Macquart, 1855) / L. mexicana Macquart, 1843 and L. caesar (Linnaeus, 1758) / L. illustris (Meigen, 1826) are paraphyletic species; to examine the relationships between the species of Lucilia and clarify the taxonomic status of Phaenicia; to estimate the relationships of Dyscritomyia, Hemipyrellia, Hypopygiopsis and Lucilia; and to assess the geographical and phylogenetic patterns of myiasis-causing behaviour in these flies.

\section{Materials and methods}

\section{DNA data}

Adult Lucilia flies were obtained from around the world (Table 1). Hemipyrellia fernandica (Macquart, 1855) were obtained from Benin, South Africa and Tanzania, and Calliphora vicina Robineau-Desvoidy, 1830 were obtained from France and used as an outgroup (Table 1). Identifications were made by the donors based on morphology and verified using published keys (Aubertin 1931, 1933, Smith 1986, Holloway 1991, Whitworth 2006, 2010). All flies were kept in separate $1.5 \mathrm{ml}$ Eppendorf tubes in 96\% ethanol or as dried pinned specimens and deposited with the Durban Natural Science Museum after analysis.

One hind leg of each fly was used for DNA analysis. DNA was extracted using the Qiagen DNeasy tissue kit (Qiagen, Inc., Valencia, CA) according to the manufacturer's instructions. Three genes were chosen for sequencing: $28 S$ rRNA (28S), a nuclear gene that has been used in previous studies and would allow comparison with other studies 


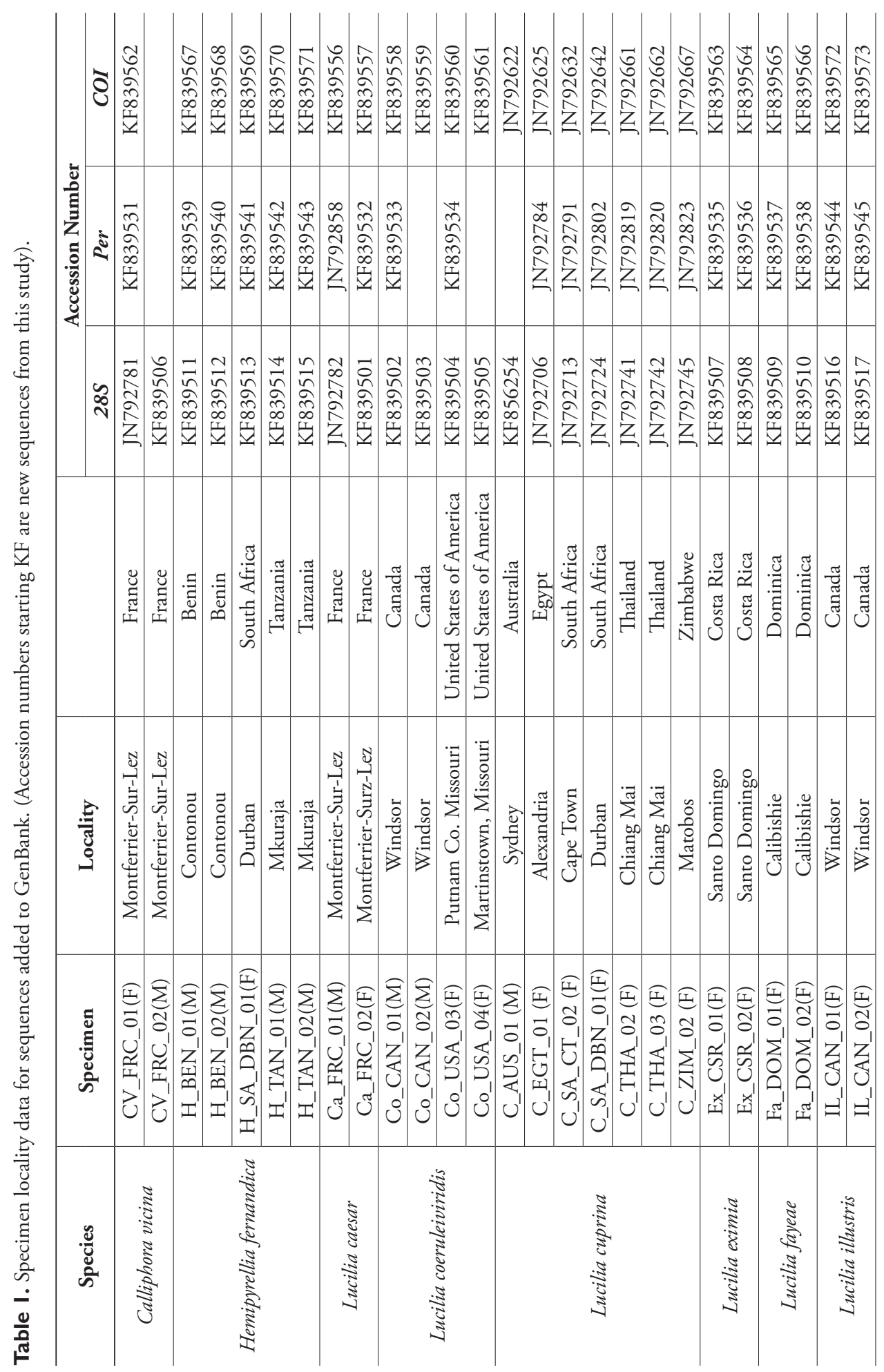




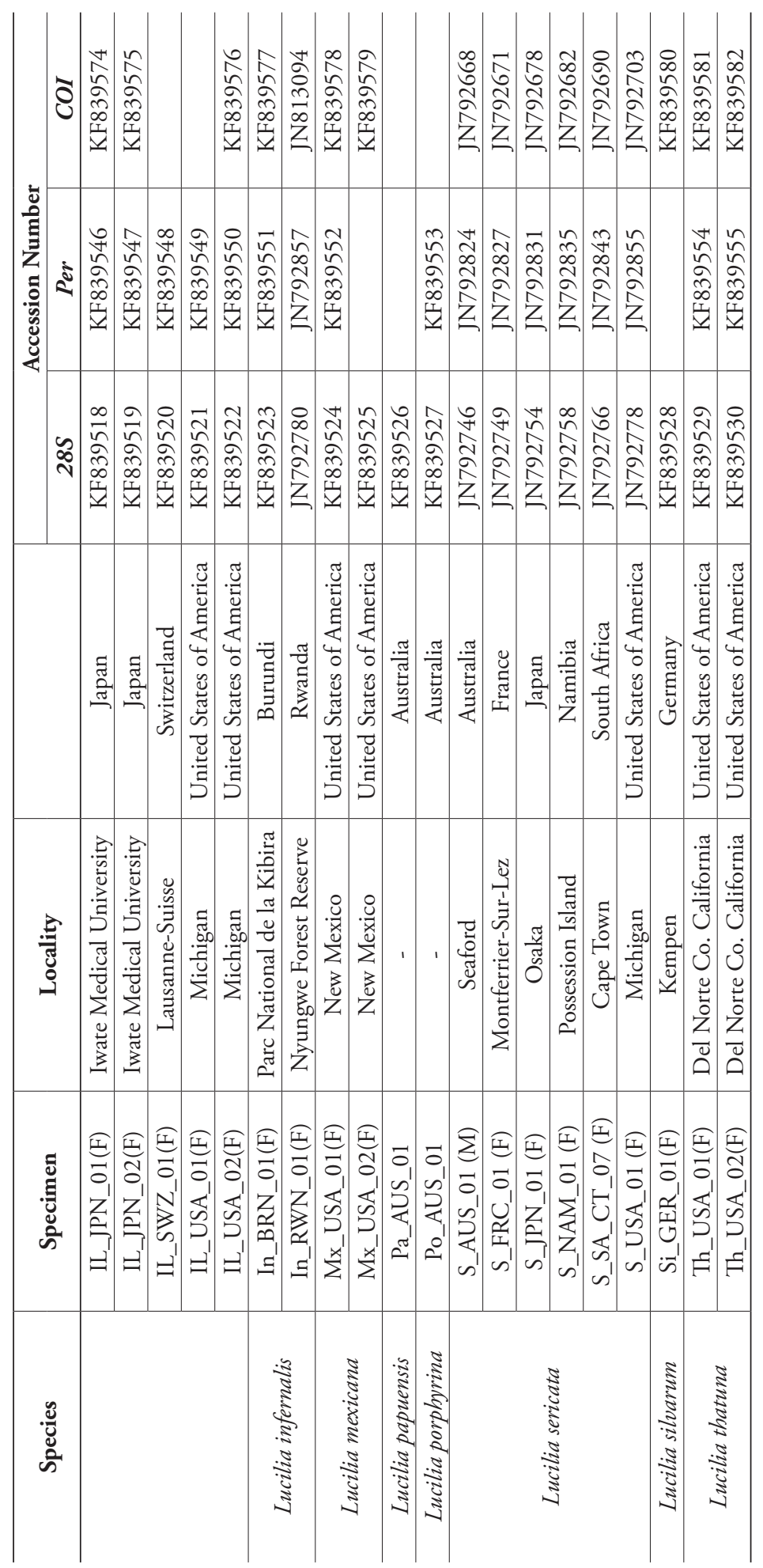


(Stevens et al. 2002, Stevens 2003, Tourle et al. 2009, DeBry et al. 2010, Sonet et al. 2012); Period (Per), a second nuclear gene that is faster-evolving than $28 S$ to give better phylogenetic resolution; and Cytochrome oxidase I (COI), the DNA barcoding gene of choice that has been used in previous studies (Stevens et al. 2002, Stevens 2003, Wallman et al. 2005, Wells et al. 2007, Harvey et al. 2008, Liu et al. 2009, Park et al. 2009, Tourle et al. 2009, DeBry et al. 2010, DeBry et al. 2012, Sonet et al. 2012). A region of approximately $650 \mathrm{bp}$ in the Domain $1-2$ of the $28 S$ gene was amplified using the primers 5'-CCCCCTGAATTTAAGCATAT-3' and 5'-TTAGACTCCTTGGTCCGTG-3' (Stevens et al. 2002). A region of approximately 600bp of the COI gene was amplified using the primers C1-J1709 (5'-ATTGGGGGGTTTGGAAATTG-3') and C1-N2353 (5'-GCTCGTGTATCAACGTCTATTCC-3') (Simon et al. 2006). A region of approximately $730 \mathrm{bp}$ of the Per gene, was amplified using the primers Per5 (5'-GCCTTCAGATACGGTCAAAC-3') (Warman, pers comm) and Per reverse (5'-CCGAGTGTGGTTTGGAGATT-3`) (designed by the authors). Polymerase chain reaction (PCR) amplification was performed using $1 \mu \mathrm{L}$ of DNA in a $25 \mu \mathrm{L}$ reaction. Amplification times were $94^{\circ} \mathrm{C}$ for 5 min denaturation, followed by 36 cycles of $94^{\circ} \mathrm{C}$ for 30 seconds, $55^{\circ} \mathrm{C}$ for $1 \mathrm{~min}, 72^{\circ} \mathrm{C}$ for 30 seconds and a final extension period at $72{ }^{\circ} \mathrm{C}$ for $7 \mathrm{~min}$. PCR products were confirmed by gel electrophoresis stained in ethidium bromide. PCR products were then sequenced using an ABI 37301 Genetic Analyzer (Applied Biosystems) and the primers used in amplification.

Additional DNA sequences of 28S, Per and COI were obtained from GenBank (www.ncbi.nlm.nih.gov) (Table 2). Additional COI barcode sequences were downloaded from the Barcode of Life Database (BOLD) website for all available Lucilia, Hemipyrellia and Hypopygiopsis species and for Paralucilia paraensis (Mello, 1972) and Chrysomya chloropyga (Wiedemann, 1818) which were included as additional outgroups. Duplicate sequences from the same studies were removed and a total of 207 sequences were included in the analysis. The sequences were aligned and edited using the BioEdit v7.0.9 software (Hall 1999).

\section{Morphological data}

The states of the 14 morphological characters defined by Stevens and Wall (1996) were obtained from Aubertin (1931, 1933), Stevens and Wall (1996) and Whitworth (2010) for all of the Lucilia and Hemipyrellia species for which sequences were available (Table 3). Museum specimens were inspected where possible to complete the character state matrix. Calliphora vicina was included as an outgroup.

\section{Phylogenetic analysis}

Separate Bayesian inference analyses were performed on each gene in MrBayes (Huelsenbeck and Ronquist 2001) using the best-fitting nucleotide substitution model 
Table 2. GenBank sequences included in this study.

\begin{tabular}{|c|c|c|c|c|c|}
\hline \multirow{3}{*}{$\begin{array}{l}\text { Species } \\
\text { C. vicina }\end{array}$} & \multirow{2}{*}{\multicolumn{2}{|c|}{ Locality }} & \multicolumn{3}{|c|}{ Accession Number } \\
\hline & & & \multirow{2}{*}{$\begin{array}{c}\mathbf{2 8 S} \\
\text { AJ300131 }\end{array}$} & \multirow[t]{2}{*}{ Per } & \multirow{2}{*}{$\begin{array}{c}\boldsymbol{C O I} \\
\mathrm{AJ} 417702 \\
\end{array}$} \\
\hline & Bristol & UK & & & \\
\hline D. fasciata & - & Hawaii & & & AY074902 \\
\hline D. lucilioides & - & Hawaii & & & AY074903 \\
\hline D. robusta & - & Hawaii & & & AY074898 \\
\hline H. ligurriens & - & China & & & DQ345092 \\
\hline H. ligurriens & - & Taiwan & & & AY097334 \\
\hline H. ligurriens & - & Taiwan & & & DQ453493 \\
\hline H. pulchra & - & China & & & DQ345091 \\
\hline L. adiosoemartoi & - & Indonesia & & & AY074901 \\
\hline L. ampullacea & Langford & UK & AJ300137 & & \\
\hline L. ampullacea & Bristol & UK & & & DQ453487 \\
\hline L. ampullacea & - & Korea & & & EU925394 \\
\hline L. bazini & - & Taiwan & & & AY346450 \\
\hline L. bazini & - & China & & & DQ345082 \\
\hline L. caesar & Langford & UK & AJ300138 & & AY417703 \\
\hline L. caesar & Bristol & UK & & & DQ453488 \\
\hline L. caesar & - & Korea & & & EU880196 \\
\hline L. cluvia & New Orleans & USA & AJ551440 & & DQ453490 \\
\hline L. cluvia & Volusia Co. Florida & USA & & & JQ942371 \\
\hline L. coeruleiviridis & New York & USA & & & FJ650558 \\
\hline L. cuprina & - & China & & & DQ345087 \\
\hline L. cuprina & Honolulu & Hawaii & & & AJ417704 \\
\hline L. cuprina & Oahu & Hawaii & & & DQ453496 \\
\hline L. cuprina & - & Taiwan & & & AY097335 \\
\hline L. cuprina & - & Thailand & & & EU418577 \\
\hline L. cuprina & Tororo & Uganda & & & AJ417711 \\
\hline L. cuprina & Townsville & Australia & AJ417709 & & AJ417710 \\
\hline L. cuprina & Waianae & Hawaii & & & AJ417705 \\
\hline L. cuprina & Wallaceville & New Zealand & & Y19108.1 & \\
\hline L. cuprina & Noordhoek & South Africa & EU626549 & & \\
\hline L. cuprina & Cincinnati & USA & FJ650542 & & \\
\hline L. eximia & - & Brazil & & & DQ453491 \\
\hline L. hainanensis & - & Taiwan & & & AY346451 \\
\hline L. hainanensis & - & China & & & DQ345084 \\
\hline L. illustris & Langford & UK & AJ300136 & & AJ551445 \\
\hline L. illustris & - & Korea & & & EU880204 \\
\hline L. illustris & - & China & & & DQ345090 \\
\hline L. illustris & - & India & & & DQ200168 \\
\hline L. mexicana & San Francisco & USA & AJ551441 & & DQ453492 \\
\hline L. mexicana & California & USA & & & FJ650563 \\
\hline L. mexicana & California & USA & & & FJ650562 \\
\hline L. papuensis & - & China & & & DQ345085 \\
\hline
\end{tabular}




\begin{tabular}{c|c|c|c|c|c}
\hline \multirow{2}{*}{ Species } & \multicolumn{2}{|c|}{ Locality } & \multicolumn{2}{c}{ Accession Number } \\
\cline { 5 - 5 } & - & Taiwan & & & Per \\
\hline L. porphyrina & - & Japan & & & AY097336 \\
\hline L. porphyrina & - & China & & & AY074900 \\
\hline L. porphyrina & Usk & - & AJ551142 & & \\
\hline L. richardsi & Perth & Australia & & & AB112833 \\
\hline L. sericata & Nerja & Spain & & & AJ417716 \\
\hline L. sericata & Kingsbury & UK & & & AJ417713 \\
\hline L. sericata & Hilerod & Denmark & AJ300140 & & EF531193 \\
\hline L. sericata & Harare & Zimbabwe & & & AJ417717 \\
\hline L. sericata & - & China & & & DQ345086 \\
\hline L. sericata & Langford & UK & AJ300139 & & \\
\hline L. sericata & Los Angeles & USA & AJ300141 & & \\
\hline L. sericata & Durham & UK & AJ551443 & & \\
\hline L. silvarum & - & USA & & & FJ650564 \\
\hline L. silvarum & Linn Co., OR & USA & & & JQ942455 \\
\hline L. silvarum & - & China & & & DQ345088 \\
\hline L. taiyuanensis & San Francisco & USA & AJ551444 & & DQ453489 \\
\hline L. thatuna & Del Norte Co., California & USA & & & JQ942464 \\
\hline L. thatuna & & &
\end{tabular}

(GTR+G in all cases) from jModelTest (Posada 2008). One cold and three hot chains were run for 5000000 generations, sampling every 1000 generations with burn-in of 1000 samples (20\%). Incongruence length difference (ILD) tests (Farris et al. 1994) were run in PAUP*4b10 (Swofford 2003) to quantify the differences in topology between trees for 28S, COI and Per. Analyses were then conducted on two combined data sets (nuclear $28 \mathrm{~S}$ and Per, and total $28 \mathrm{~S}$, Per and $\mathrm{COI}$ ), each partitioned by gene, with the parameters as above.

A network analysis for the $C O I$ data was created using the NeighborNet algorithm in SplitsTree4 (Huson and Bryant 2008) and the uncorrected P-distance method.

The COI barcode sequences ( -700 bp long, between base numbers 1490 and 2198) retrieved from on-line databases were aligned along with our new sequences $(-640 \mathrm{bp}$ long, between base numbers 1709 and 2353) for a region approximately 800 bp long in which every sequence overlapped the others by at least $490 \mathrm{bp}$. Bayesian inference analysis was performed in MrBayes (Huelsenbeck and Ronquist 2001) using the bestfitting nucleotide substitution model $(G T R+G)$ from jModelTest (Posada 2008).

Maximum parsimony analysis of the morphological data (Table 3) using Fitch parsimony was performed in Paup*4b10 (Swofford 2003). Statistical support for nodes was assessed by bootstrapping with 100 replicates retaining a maximum of 10000 trees. Strict consensus and 50\% majority rule trees were produced from the analysis.

The zoogeographic distributions of species in the Luciliinae (Table 4) were mapped onto the trees. 


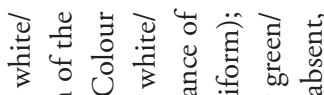

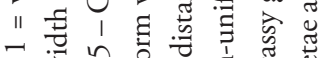

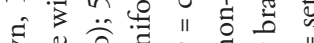
है ड ड 3 है

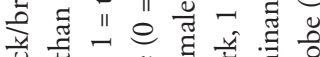
ज : उ ¿ น पे० 苟 \&

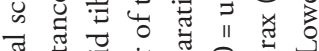

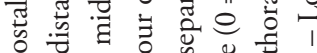
.

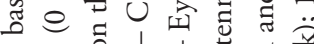

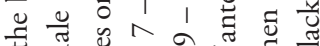

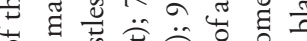
O

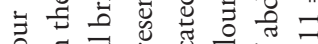
응 $\exists$ 劳 U 0 웅

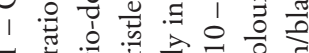

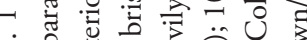
¿ वे

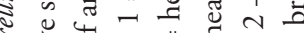

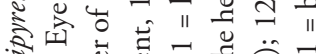

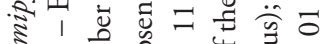

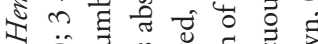

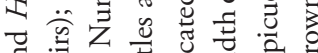
चี ज्ञ 1 जू ¿

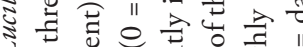
॥ एँ

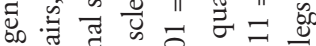
કั ए

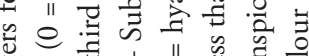
¿ đั山

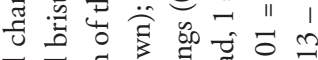
సี

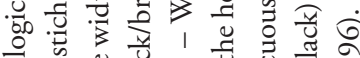

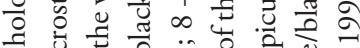
로을

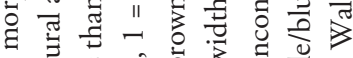

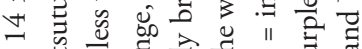

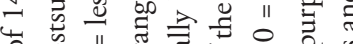

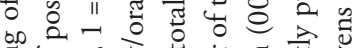

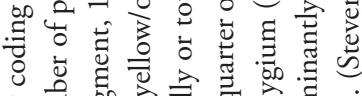

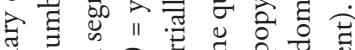

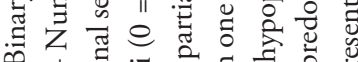
๑

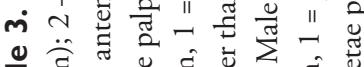
을 छ

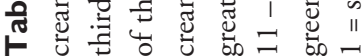

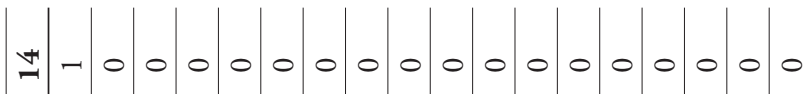

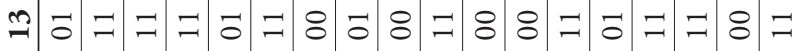

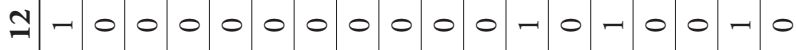

$$
\begin{aligned}
& \text { ニ }
\end{aligned}
$$

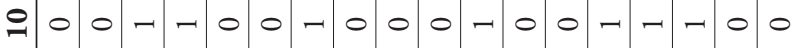

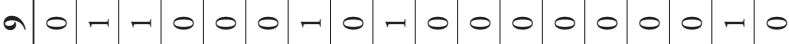

$$
\begin{aligned}
& \text { 竎 }
\end{aligned}
$$

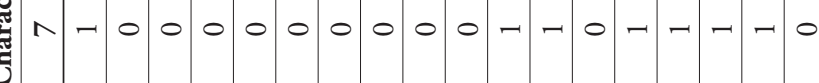

$$
\begin{aligned}
& 00-1-n-00-00000-1-0-1-0
\end{aligned}
$$

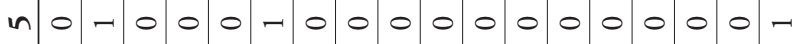

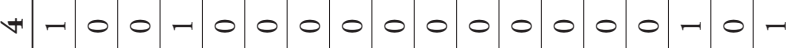

$$
\begin{aligned}
& n-000-0-1-00-1-1-1-10
\end{aligned}
$$

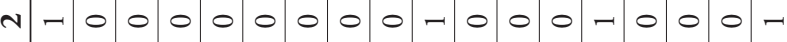

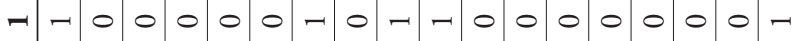

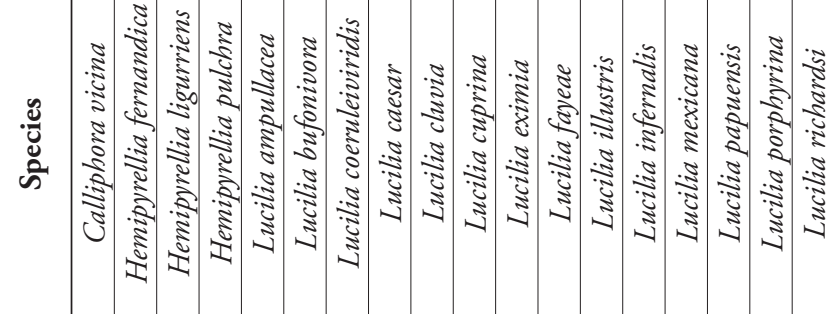




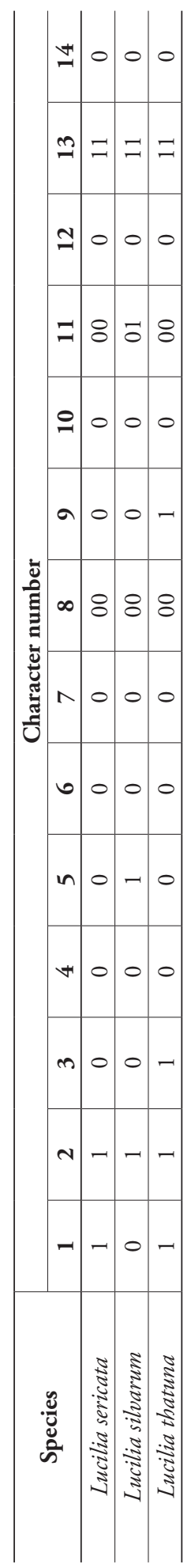


Table 4. Zoogeographic distribution of species of Luciliinae included in this study. Symbols in brackets represent anthropogenic introductions.

\begin{tabular}{|c|c|c|c|c|c|c|c|}
\hline \multirow{2}{*}{ Species } & \multicolumn{7}{|c|}{ Region } \\
\hline & Hawaii & Afrotropical & Australasian & Oriental & Palaearctic & Neararctic & Neotropical \\
\hline Dysctritomyia spp. & $\mathrm{X}$ & & & & & & \\
\hline Hypopygiopsis spp. & & & $\mathrm{X}$ & $\mathrm{X}$ & & & \\
\hline Hemipyrellia spp. & & $\mathrm{X}$ & $\mathrm{X}$ & $\mathrm{X}$ & & & \\
\hline H. fernandica & & $\mathrm{X}$ & & & & & \\
\hline L. infernalis & & $\mathrm{X}$ & & & & & \\
\hline L. cuprina & & $\mathrm{X}$ & $\mathrm{X}$ & $\mathrm{X}$ & $(\mathrm{X})$ & $\mathrm{X}$ & \\
\hline L. sericata & & $(\mathrm{X})$ & $(\mathrm{X})$ & $\mathrm{X}$ & $\mathrm{X}$ & $\mathrm{X}$ & $(\mathrm{X})$ \\
\hline L. silvarum & & & & & $\mathrm{X}$ & $\mathrm{X}$ & \\
\hline L. thatuna & & & & & & $\mathrm{X}$ & \\
\hline L. adiosoemartoi & & & & $\mathrm{X}$ & & & \\
\hline L. bazini & & & & $\mathrm{X}$ & & & \\
\hline L. hainanensis & & & & $\mathrm{X}$ & & & \\
\hline L. taiyuanensis & & & & $\mathrm{X}$ & & & \\
\hline L. papuensis & & & $\mathrm{X}$ & $\mathrm{X}$ & & & \\
\hline L. porphyrina & & & $\mathrm{X}$ & $\mathrm{X}$ & $\mathrm{X}$ & & \\
\hline L. ampullacea & & & & $\mathrm{X}$ & $\mathrm{X}$ & & \\
\hline L. caesar & & & & $\mathrm{X}$ & $\mathrm{X}$ & & \\
\hline L. illustris & & & & $\mathrm{X}$ & $\mathrm{X}$ & $\mathrm{X}$ & \\
\hline L. cluvia & & & & & $\mathrm{X}$ & $\mathrm{X}$ & \\
\hline L. coeruleiviridis & & & & & & $\mathrm{X}$ & \\
\hline L. mexicana & & & & & & $\mathrm{X}$ & \\
\hline L. fayeae & & & & & & & $\mathrm{X}$ \\
\hline L. eximia & & & & & & & $\mathrm{X}$ \\
\hline
\end{tabular}

\section{Results}

\section{Molecular data}

Sequencing of the 28S, Per and COI genes resulted in 1932 bp being aligned $-656 \mathrm{bp}$ for $28 S, 700 \mathrm{bp}$ for Per and 576 bp for COI. A total of 46 specimens were sequenced for 28S, 41 specimens for Per and 39 specimens for COI. These sequences were submitted to GenBank (Table 1).

The ILD test for $28 S$ and Per showed these two genes to be highly congruent ( $\mathrm{p}$ $=1.00)$ and the datasets were therefore concatenated for the analyses. The ILD test for $28 S, \operatorname{Per}$ and COI showed the combination of these genes to be incongruent $(\mathrm{p}=$ 


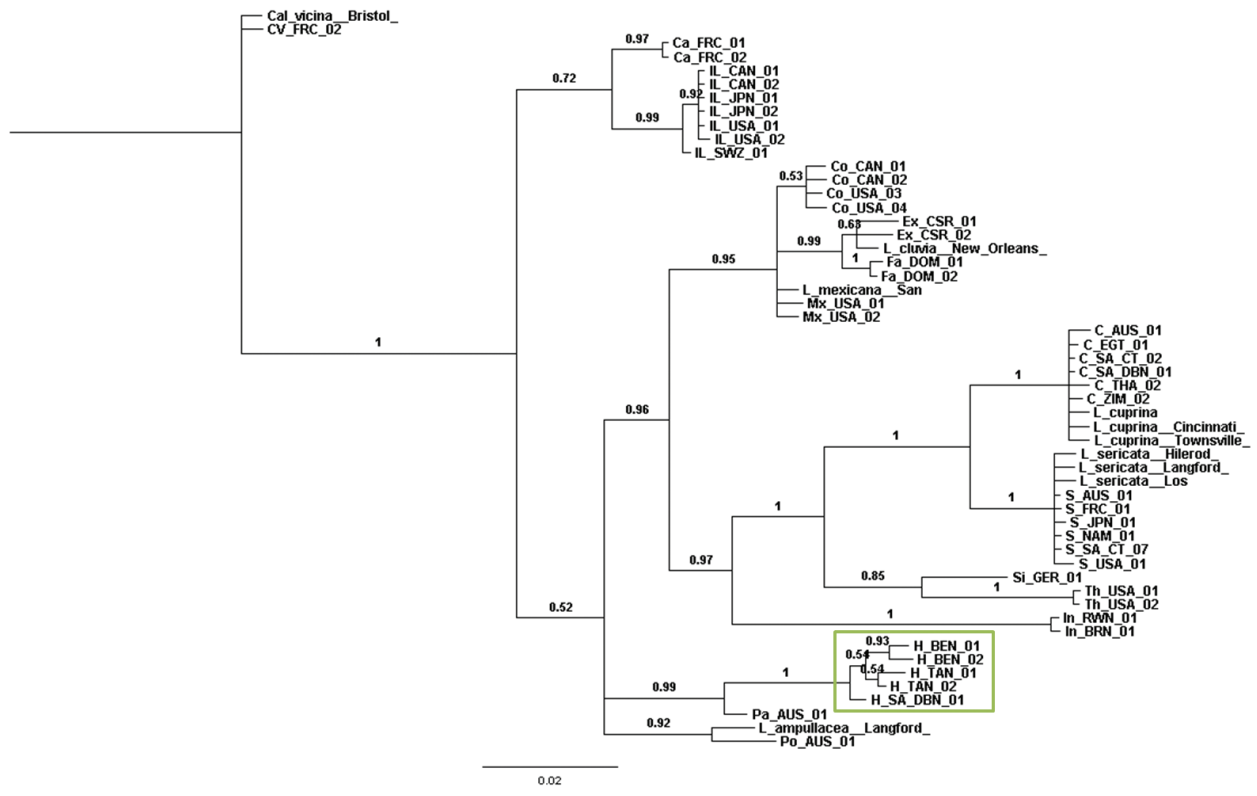

Figure I. Bayesian inference tree constructed from concatenated nuclear genes $28 S+$ Per. Posterior probabilities are indicated on nodes. Green box $=$ Hemipyrellia fernandica $. \mathrm{C}=$ L. cuprina, $\mathrm{Ca}=$ L. caesar, $\mathrm{Co}$ $=L$. coeruleiviridis, $\mathrm{CV}=$ Calliphora vicina, $\mathrm{Ex}=$ L. eximia, $\mathrm{Fa}=L$. fayeae, $\mathrm{H}=$ Hemipyrellia fernandica, $\mathrm{IL}=$ L. illustris, $\mathrm{In}=$ L. infernalis, $\mathrm{Mx}=$ L. mexicana, $\mathrm{Pa}=$ L. papuensis, $\mathrm{Po}=$ L. porphyrina, $\mathrm{S}=$ L. sericata, $\mathrm{Si}=L$. silvarum, $\mathrm{Th}=L$. thatuna, $\mathrm{AUS}=$ Australia, $\mathrm{BRN}=$ Burundi, $\mathrm{CAN}=\mathrm{Canada}, \mathrm{CSR}=$ Costa Rica, $\mathrm{DOM}=$ Dominican Republic, FRC $=$ France, GER $=$ Germany, JPN $=$ Japan, NAM = Namibia, EGT $=$ Egypt, RWN = Rwanda, SWZ = Switzerland, SA = South Africa, TAN = Tanzania, THA = Thailand, USA $=$ United States of America, ZIM = Zimbabwe. DBN = Durban, CT = Cape Town.

0.03). Despite the incongruence between the nuclear ( $28 S$ and $P e r)$ and mitochondrial (COI) data, these data sets were also concatenated and an analysis run on the total molecular evidence.

The Bayesian inference tree (Fig. 1) for the nuclear genes (28S and Per) clearly showed that L. sericata and L. cuprina are sister clades with 100\% support. Lucilia thatuna Shannon, 1926 and L. silvarum Meigen, 1826 form a sister clade to the $L$. sericata $+L$. cuprina clade. The specimens of $H$. fernandica all grouped together and were sister to L. papuensis Macquart, 1843. The Hemipyrellia clade sat within the Lucilia clade (Fig. 1).

In the Bayesian inference tree for the mitochondrial gene (COI) (Fig. 2), L. cuprina was paraphyletic with respect to $L$. sericata. The $L$. cuprina $+L$. sericata clade was poorly resolved with respect to the L. silvarum + L. taiyuanensis Chu, 1975 clade. The $H$. fernandica sequences grouped with those of $H$. ligurriens and $H$. pulchra from GenBank and this clade was sister to Lucilia infernalis Villeneuve, 1914. This Hemipyrellia + L. infernalis clade sat within the Lucilia clade on the tree. Two specimens from Taiwan assigned to $H$. ligurriens grouped with the L. cuprina specimens. The three 


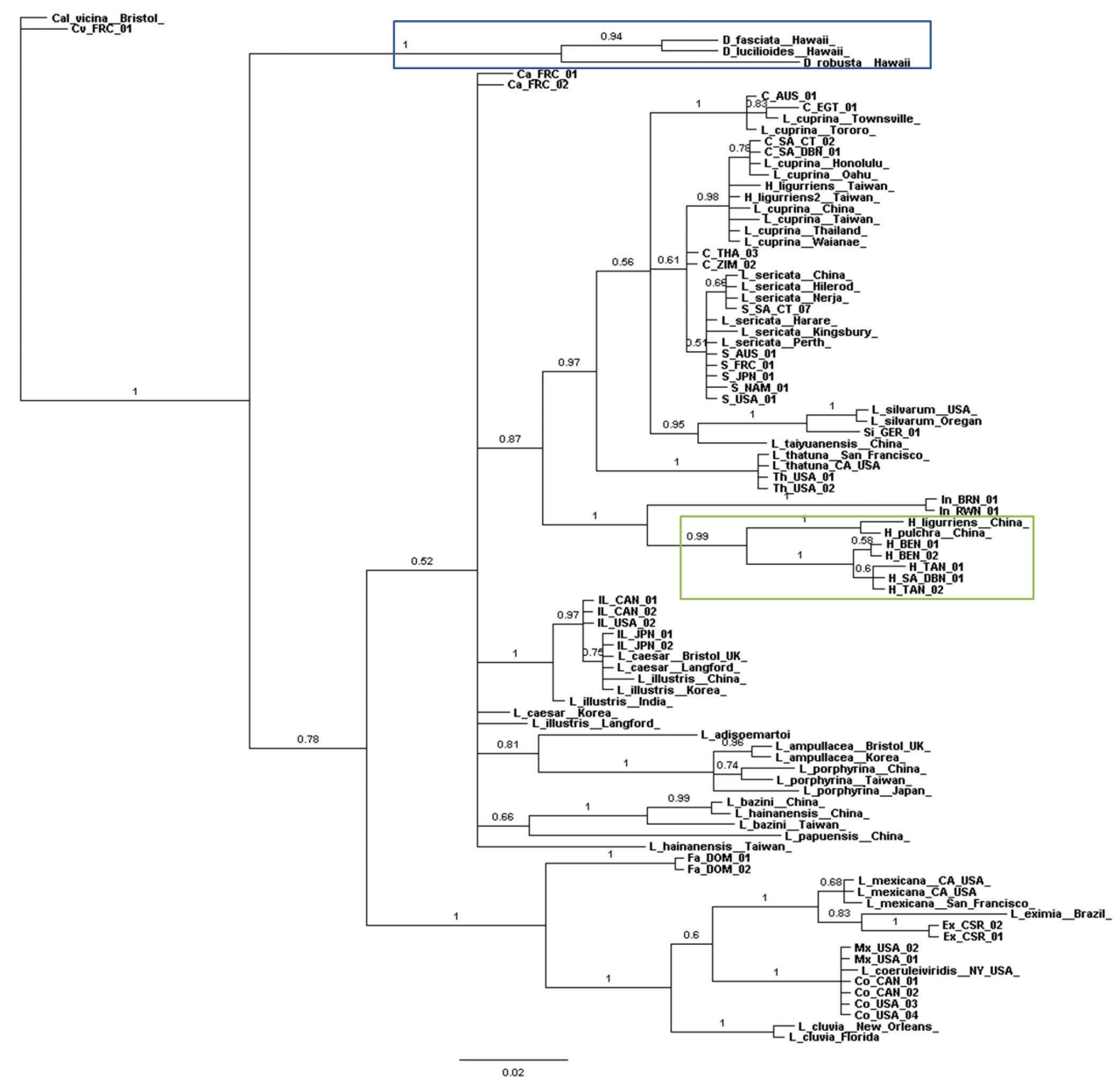

Figure 2. Bayesian inference tree constructed from mitochondrial gene COI. Posterior probabilities indicated on nodes. Green box $=$ Hemipyrellia sp. Blue box $=$ Dysctritomyia sp. C $=$ L. cuprina, $\mathrm{Ca}=$ L. caesar, $\mathrm{Co}=$ L. coeruleiviridis, $\mathrm{CV}=$ Calliphora vicina, $\mathrm{Ex}=$ L. eximia, $\mathrm{Fa}=$ L. fayeae, $\mathrm{H}=$ Hemipyrellia fernandica $\mathrm{IL}=$ L. illustris, $\mathrm{In}=$ L. infernalis, $\mathrm{Mx}=L$. mexicana, $\mathrm{S}=$ L. sericata, $\mathrm{Si}=L$. silvarum, $\mathrm{Th}=$ L. thatuna, AUS $=$ Australia, $\mathrm{BRN}=$ Burundi, $\mathrm{CAN}=$ Canada, $\mathrm{CSR}=$ Costa Rica, $\mathrm{DOM}=$ Dominican Republic, FRC $=$ France, GER $=$ Germany, JPN $=$ Japan, NAM $=$ Namibia, EGT $=$ Egypt, RWN $=$ Rwanda, SWZ $=$ Switzerland, $S A=$ South Africa, TAN $=$ Tanzania, THA $=$ Thailand, USA = United States of America, $\mathrm{ZIM}=$ Zimbabwe. DBN = Durban, CT = Cape Town .

Dyscritomyia sequences included in the analysis grouped together monophyletically outside Lucilia.

The Bayesian inference tree for the incongruent concatenated total evidence molecular dataset (28S, Per and COI) (Fig. 3) showed L. sericata and L. cuprina to be sister clades with strong support. The $H$. fernandica sequences sat within Lucilia, and the rest of the tree was topologically similar to the gene trees. 


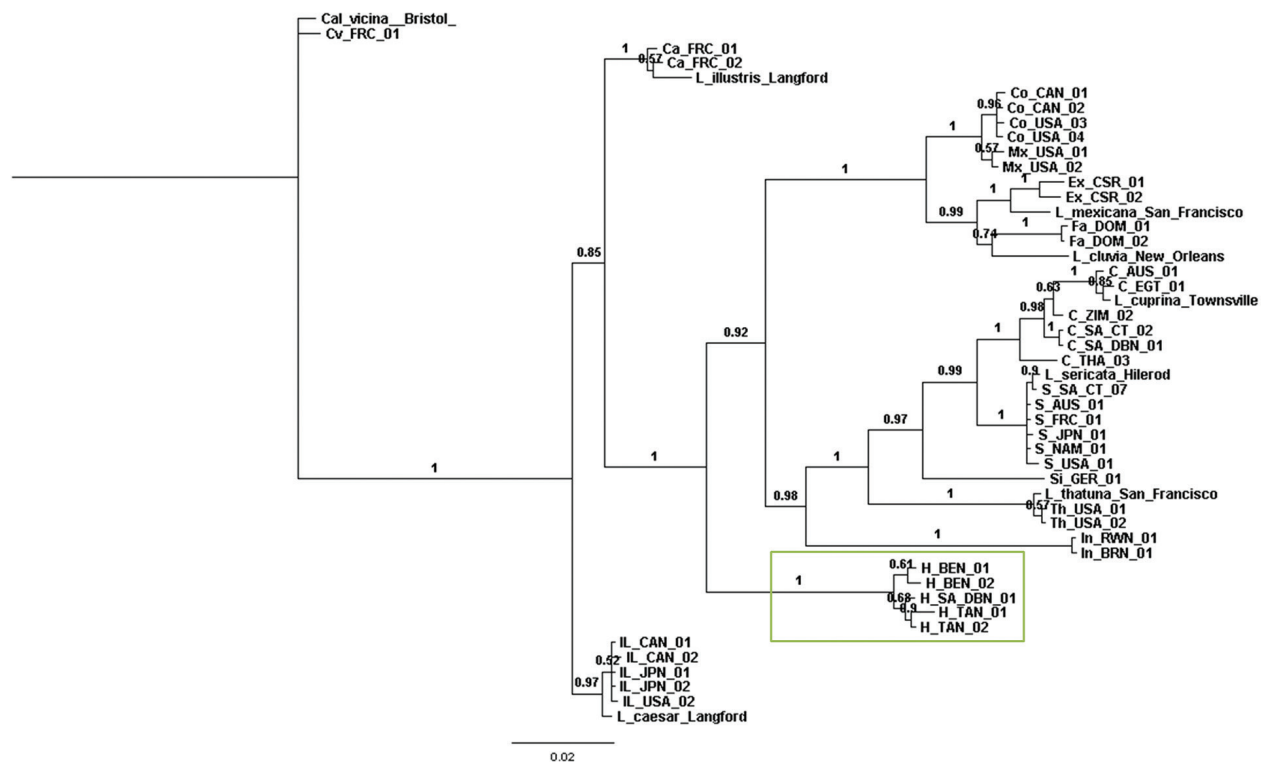

Figure 3. Bayesian inference tree constructed from the concatenated nuclear (28S \& Per) and mitochondrial $(C O I)$ genes. Posterior probabilities indicated on nodes. Green box $=$ Hemipyrellia fernandica $. \mathrm{C}=$ L. cuprina, $\mathrm{Ca}=$ L. caesar, $\mathrm{Co}=$ L. coeruleiviridis, $\mathrm{CV}=$ Calliphora vicina, $\mathrm{Ex}=$ L. eximia, $\mathrm{Fa}=$ L. fayeae, $\mathrm{H}=$ Hemipyrellia fernandica $\mathrm{IL}=L$. illustris, $\mathrm{In}=L$. infernalis, $\mathrm{Mx}=$ L. mexicana, $\mathrm{S}=$ L. sericata, $\mathrm{Si}=L$. silvarum, $\mathrm{Th}=$ L. thatuna, $\mathrm{AUS}=$ Australia, $\mathrm{BRN}=$ Burundi, $\mathrm{CAN}=$ Canada, $\mathrm{CSR}=$ Costa Rica, $\mathrm{DOM}$ $=$ Dominican Republic, FRC $=$ France, GER $=$ Germany, JPN = Japan, NAM = Namibia, EGT = Egypt, RWN = Rwanda, SWZ = Switzerland, SA = South Africa, TAN = Tanzania, THA = Thailand, USA = United States of America, ZIM = Zimbabwe. DBN = Durban, CT = Cape Town.

The NeighborNet analysis (Fig. 4) clearly showed seven distinct major splits. The New World species (L. coeruleiviridis, L. cluvia Walker, 1849, L. eximia Wiedemann, 1819, L. mexicana and L. fayeae Whitworth, 2010) grouped together; L. caesar, L. illustris, L. porphyrina Walker, 1856, L. ampullacea Villeneuve, 1922, L. adiosoemartoi, L. papuensis Macquart, 1843, L. bazini Séguy, 1934 and L. hainanensis Fan, 1965 formed a group; L. infernalis was isolated, as was H. fernandica; the bulk of the Lucilia species that are primary facultative parasites (L. sericata, L. cuprina, $L$. silvarum and $L$. thatuna) grouped together; and Calliphora vicina and the Dyscritomyia species as the outgroups formed separate but neighbouring splits.

Bayesian inference analysis of the COI barcode data set generated a tree (Fig. 5) with very strong posterior probabilities for most clades except for the $L$. sericata $+L$. cuprina $+L$. taiyuanensis $(\mathrm{p}=0.61)$ and $L$. caesar + L. illustris $(\mathrm{p}=0.58)$ clades. The Hemipyrellia species all formed a distinct clade within Lucilia with 100\% support. One of the Hypopygiopsis infumata (Bigot, 1877) sequences forms a clade with L. hainanensis + L. papuensis + L. bazini and the other sequence groups with the Hemipyrellia sequences. Paralucilia paraensis sat outside Lucilia with Chrysomya chloropyga, confirming its classification as a chrysomyine. 


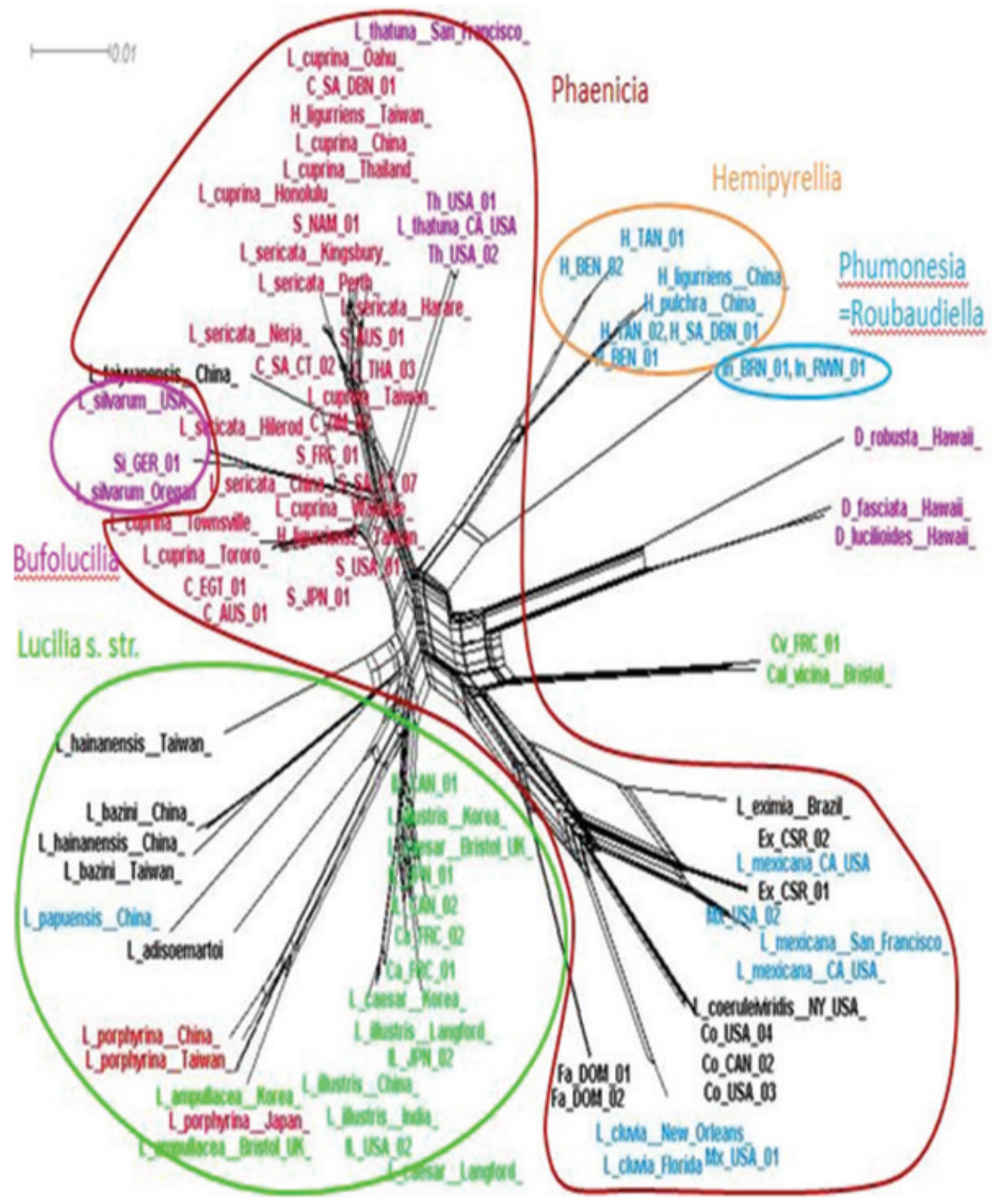

Figure 4. NeighborNet network diagram constructed from COI data showing parasitic behaviour (coloured text) and previous sub-generic status of Lucilia according to Hall (1948) (ellipses). Text colours: Red $=$ primary facultative parasite, green $=$ secondary facultative parasite, purple $=$ parasite (unknown if primary or secondary), blue $=$ saprophage, black $=$ unknown parasitic behaviour. $\mathrm{C}=$ cuprina, $\mathrm{Ca}=$ caesar, $\mathrm{Co}=$ coeruleiviridis, $\mathrm{CV}=$ Calliphora vicina, $\mathrm{Ex}=$ eximia, $\mathrm{Fa}=$ fayeae, $\mathrm{H}=$ Hemipyrellia fernandica, $\mathrm{IL}=$ illustris, $\mathrm{In}=$ infernalis, $\mathrm{Mx}=$ mexicana, $\mathrm{S}=$ sericata, $\mathrm{Si}=$ silvarum, $\mathrm{Th}=$ thatuna, $\mathrm{AUS}=$ Australia, $\mathrm{BRN}$ $=$ Burundi, $\mathrm{CAN}=$ Canada, $\mathrm{CSR}=$ Costa Rica, $\mathrm{DOM}=$ Dominica, FRC $=$ France, GER $=$ Germany, JPN = Japan, NAM = Namibia, EGT = Egypt, RWN = Rwanda, SWZ = Switzerland, SA = South Africa, TAN = Tanzania, THA = Thailand, USA = United States of America, ZIM = Zimbabwe. DBN = Durban, $\mathrm{CT}=$ Cape Town . 


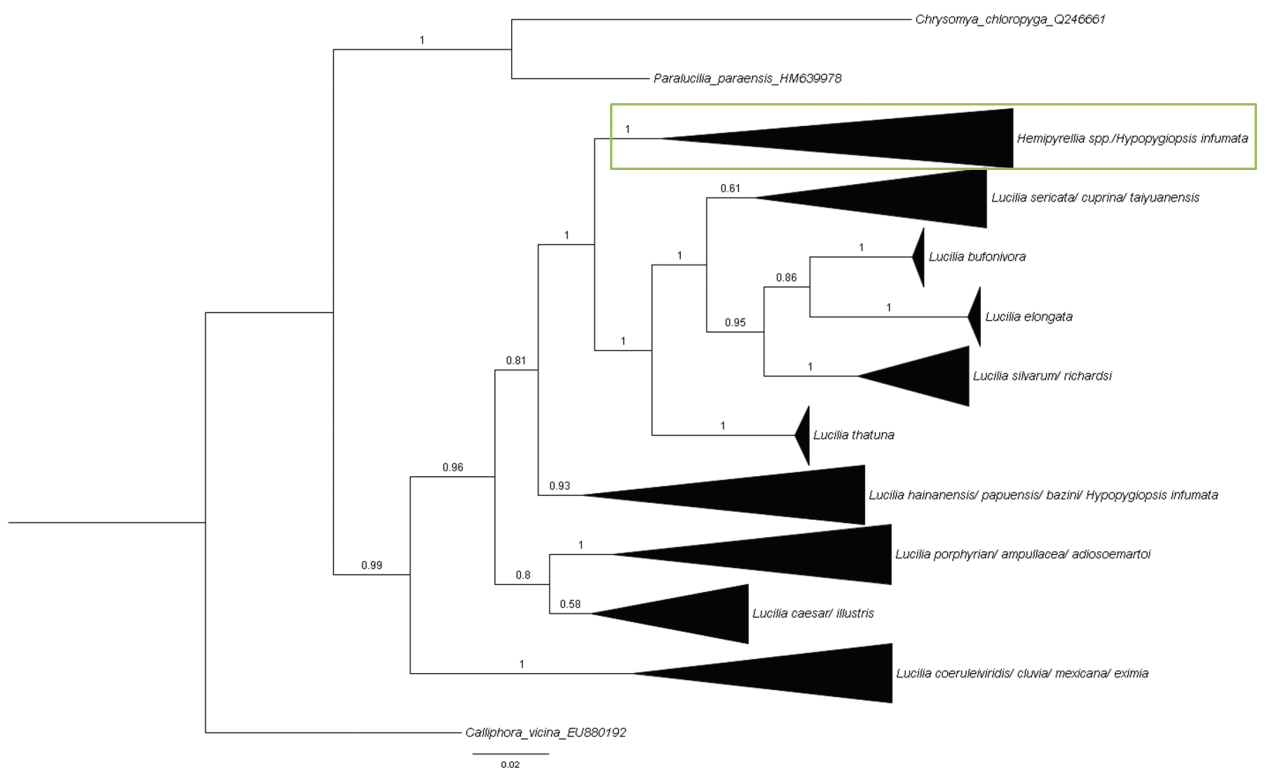

Figure 5. Bayesian inference tree constructed using COI barcode sequences. Posterior probabilities indicated on nodes. Support within the collapsed nodes is variable. Green box $=$ Hemipyrellia sp.

\section{Morphological data}

The strict consensus parsimony tree for the morphological characters was largely uninformative, forming only two clades, with the majority of the species being unresolved (tree not shown). The 50\% majority rule consensus tree (Fig. 6) grouped L. sericata, $L$. cuprina, L. silvarum, L. bufonivora and L. thatuna together. Lucilia coeruleiviridis and L. cluvia grouped together in all of the trees. The Hemipyrellia species formed a clade within Lucilia, and L. caesar and L. illustris grouped together.

\section{Discussion}

The majority rule consensus tree of the morphological characters (Fig. 6) was largely incongruent with the molecular phylogenetic trees (Figs $1-3,5$ ). The only clade that was congruent contains $L$. sericata + L. cuprina $+L$. richards + L. silvarum + L. bufonivora + L. thatuna. In the COI Bayesian inference tree this clade included L. elongata too (Fig. 5). This is partly due to disparities in taxon sampling and possibly partly a result of the limited character set available for the morphological parsimony analysis. It is ideal to have at least three times more characters than species in this type of analysis (Stevens and Wall 1996), whereas the matrix has 21 species and 17 character states, which limits the conclusions about general trends that can be drawn from these morphological data. This discussion will therefore focus on the results of the molecular analyses. 


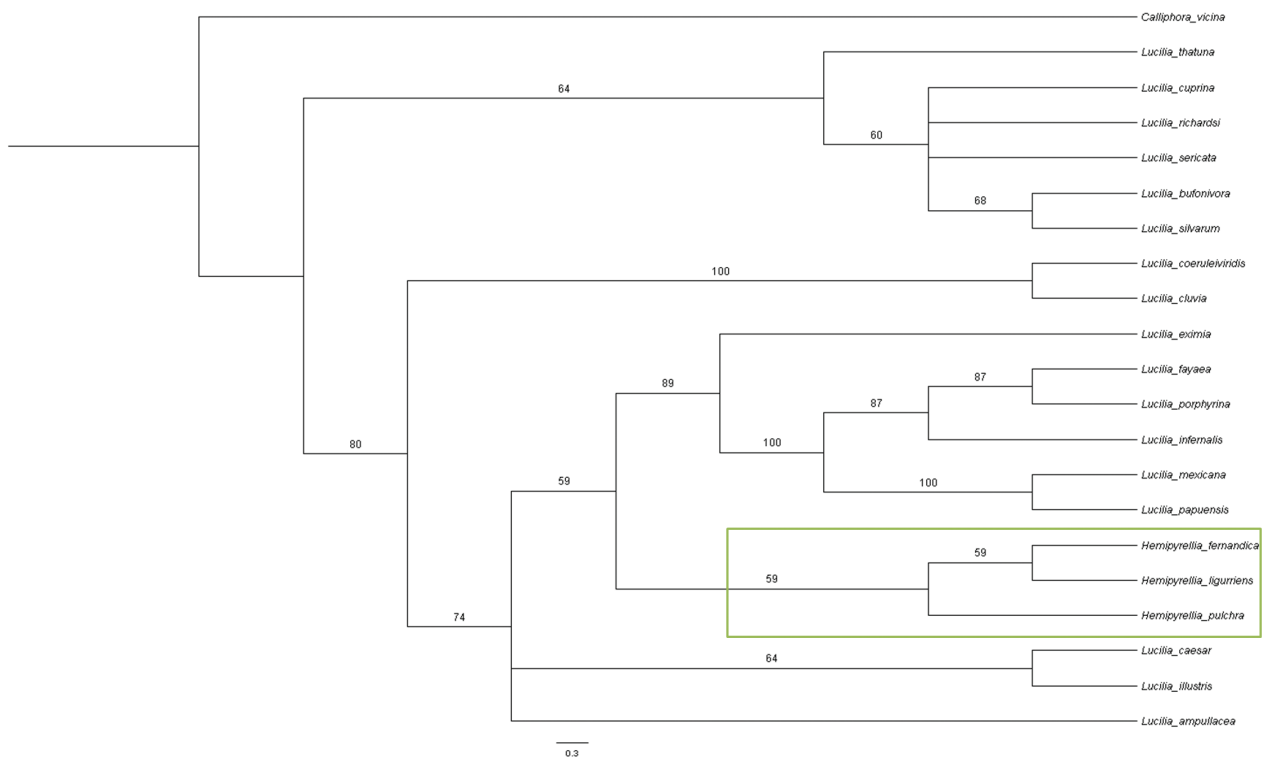

Figure 6. Majority rule consensus tree for 21 species of Lucilia and Hemipyrellia constructed from morphological characters listed in Table 3 . Green box $=$ Hemipyrellia $\mathrm{sp}$.

\section{Relationship of L. sericata and L. cuprina}

Although only about half of the Lucilia species listed as valid by Aubertin (1933) were included in this study, these results strongly suggest that L. sericata and L. cuprina are indeed sister species. All of the Bayesian inference analyses (Figs 1-3) indicated this with strong support from the nuclear genes $(28 S$ and Per) and total evidence $(28 S+$ Per + COI) trees and weaker support from the COI gene alone. Lucilia cuprina was paraphyletic (Fig. 2) with respect to L. sericata in the mitochondrial gene (COI) tree, as shown previously (using the same sequences but weaker auxiliary taxon sampling) to be the result of introgressive hybridisation between these two species (Williams and Villet 2013). In another study (McDonagh and Stevens 2011), the nuclear gene elongation factor-1 alpha (EF-1a) did not recover $L$. sericata and $L$. cuprina as sister-species, but the clade containing $L$. sericata was poorly resolved and thus the conclusion was weakly supported, but the $28 S$ and $C O I$ gene trees both recovered $L$. sericata and $L$. cuprina as sister species with strong support (McDonagh and Stevens 2011).

\section{Molecular identification of Lucilia species}

It has already been established that $L$. sericata and $L$. cuprina show a case of ancient introgression, and that they still interbreed (Williams and Villet 2013). This is a widely 
acknowledged problem for identification using partial COI sequences alone (Rubinoff et al. 2006, Nelson et al. 2007, Roe and Sperling 2007, Williams et al. 2008, Tantawi et al. 2010, Williams and Villet 2013). Other problematic species pairs occur in the genus (DeBry et al. 2012, Sonet et al. 2012), and it is important to recognise the cause(s) and to document genes that are more useful for identification in these contexts.

In the Bayesian inference trees based on mitochondrial (COI) (Fig. 2) and total evidence (28S, Per and COI) (Fig. 3), L. mexicana was paraphyletic with respect to L. coeruleiviridis. This has been observed in the continental United States of America (DeBry et al. 2012), where these two species were found to share a mitochondrial haplotype. The $L$. mexicana specimens with this $L$. coeruleiviridis haplotype appear to be limited to a geographic area including Texas and New Mexico (DeBry et al. 2012). This study independently confirms this pattern, since our new sequences of $L$. mexicana from New Mexico grouped with $L$. coeruleiviridis, and the GenBank specimens of $L$. mexicana from California formed a distinct clade (Figs 2-3). This suggests introgression between $L$. mexicana and $L$. coeruleiviridis. The nuclear genes separated $L$. coeruleiviridis and $L$. mexicana, although $L$. mexicana was not resolved in this analysis (Fig 1). In the Bayesian inference tree based on the Per gene alone (tree not shown), these two species are recovered as sister clades with 100\% support, which suggests that nuclear genes will separate these two species as they do for $L$. sericata and $L$. cuprina (Williams and Villet 2013).

Lucilia caesar and L. illustris also share haplotypes (Sonet et al. 2012). In the COI tree (Fig. 2), L. caesar specimens from France and Korea and one specimen of $L$. illustris from the UK were not resolved, but the remainder of the L. caesar and L. illustris specimens formed a mixed clade with $100 \%$ support. These two species can therefore not be unambiguously identified using only COI. The nuclear genes in this study (Fig. 1) separated these two species but used only two specimens of $L$. caesar from France and seven specimens of L. illustris from Japan, Switzerland, Canada and the United States of America. Including specimens from other countries may give a different result as was seen in a previous study (Sonet et al. 2012) where L. caesar and L. illustris could not be reliably identified using either mitochondrial or nuclear genes as the intraspecific and interspecific genetic distances were very low. This might result from hybridisation or incomplete lineage sorting (Sonet et al. 2012).

These three species pairs highlight the need for using more than one gene to identify species, as has been suggested in previous studies (Rubinoff et al. 2006, Nelson et al. 2007, Roe and Sperling 2007, Williams et al. 2008, Tantawi et al. 2010, Williams and Villet 2013). It also highlights a problem in using COI as a universal 'barcoding' gene (Rubinoff et al. 2006, Roe and Sperling 2007, Whitworth et al. 2007, Sonet et al. 2012, van Nieukerken et al. 2012, Jordaens et al. 2013), especially in a forensic context. While cases of ancient introgression remain genetically identifiable (DeBry et al. 2012, Williams and Villet 2013), cases of incomplete lineage sorting may be intractable, and morphological identification may be the best solution, especially if the identifications need to go to court. 


\section{Diversification of Luciliinae}

The Luciliinae showed two strong patterns underlying their diversification: biogeographical radiation and the diversification of parasitism.

The analyses (summarised in Fig. 4) showed geographically distinct clusters of species from the New World (L. eximia $+L$. mexicana + L. coeruleiviridis $+L$. cluvia $+L$. fayeae), the Oriental region (L. hainanensis + L. bazini + L. papuensis + L. adiosoemarto $i$ Kurahashi, 1988), and Eurasia (L. porphyrina + L. ampullacea). Hemipyrellia formed a monophyletic Old World lineage (Aubertin 1931). Lucilia infernalis is found only in Africa (Aubertin 1933) and the sequences from Rwanda and Burundi formed a separate group. One component of phylogenetic diversification within Lucilia is therefore certainly biogeographical.

Lucilia sericata, L. cuprina, $L$. thatuna and $L$. silvarum form a clade of facultatively parasitic species, with $L$. sericata and $L$. cuprina being primary facultative parasites. This group is geographically diverse, with only $L$. thatuna being restricted to one region, the United States of America. Likewise, L. caesar and L. illustris form a clade that represents secondary facultative parasites. Lucilia illustris is Holarctic, while $L$. caesar is restricted to the Palaearctic (DeBry et al. 2012). Dyscritomyia is endemic to the Hawaiian Islands (Wells et al. 2002) and phylogenetically coherent. Its members are attracted to carrion and are suspected of breeding in carrion and parasitizing snails (Hardy 1981).

Many Lucilia species are myiasis-causing (Zumpt 1965), with L. cuprina being the most recognised and often referred to as the sheep-strike blowfly (Hepburn 1943, Ullyett 1945, Vogt and Woodburn 1979, Heath and Bishop 2006). Other species of Lucilia known to be facultative parasites include L. sericata, L. silvarum, $L$. thatuna, L. richardsi, L. porphyrina, L. illustris, $L$. caesar, and L. ampullacea; the only obligately parasitic species in the genus are L. bufonivora and possibly L. elongata (Aubertin 1933, Hall 1948, Zumpt 1965, Rognes 1991, McDonagh and Stevens 2011). There are also saprophagous species within Lucilia, including L. mexicana, L. cluvia, L. papuensis and L. infernalis (Hall 1948, Zumpt 1965). None of these different parasitic behaviours are limited to any particular geographical area (Fig. 4). This implies that diversification of breeding behaviours has also been a component of phylogenetic diversification within Lucilia, independent of biogeography.

\section{Taxonomy of Luciliinae}

Lucilia Robineau-Desvoidy, 1830 (type species: Lucilia caesar (Linnaeus, 1758) has a complex nomenclatural history that is integrally related to its biogeographical and dietary radiation. Several authors including Bigot, van der Wulp, Brauer and Bergenstamm, Girschner, Hough, Kramer, Shannon and Malloch (Aubertin 1933) contributed to the ultimate development of this genus. Early studies of the European Lucilia 
were conducted by Stein (1924), Richards (1926), Collin (1926) and Séguy (1928) and Shannon published on the North and South Amercican Lucilia (1926) (Aubertin 1933). Aubertin (1933) published the most comprehensive review of the genus and recognised 27 species. This genus is widely spread across with world. The adults of this genus feed on nectar, carrion and decomposing material and the females are oviparous (Aubertin 1933). The larvae of this genus develop on decomposing animal material. Several species have developed specialised parasitic behaviour such as L. cuprina, which lays its eggs on living sheep and the larvae feed on the live animals, causing myiasis. Lucilia bufonivora is a parasite of toads.

Phaenicia Robineau-Desvoidy, 1863 (type species: Phaenicia concinna RobineauDesvoidy, 1863 = Musca sericata Meigen, 1826) has a history of varied usage. Hall (1948) divided Lucilia into several separate genera including Bufolucilia, Phaenicia and Lucilia sensu stricto. Hall's (1948) separation of species into the genera Phaenicia and Lucilia was primarily based on the presence or absence of bristles on the subcostal sclerite and the character of the ocellar triangle. In contrast, Malloch (1926) used the yellow colour of the basicostal scale and the presence of three postsutural acrostichal bristles to define his concept of Phaenicia. The use of Phaenicia has persisted in North American literature (Stevens and Wall 1996, Byrd and Castner 2010), but is not generally used in other parts of the world as it is seen as a junior synonym of Lucilia (Zumpt 1965).

In the network analysis (Fig. 4), the species that would be assigned to Phaenicia based on Hall's (1948) criteria can clearly be seen to be part of two distant clades. These species occur in both the Old and New Worlds, showing vast geographic ranges. The group includes species that are primary facultative parasites and species that are saprophages. Hall's (1948) usage of Lucilia s.str. refers only to Lucilia illustris (and L. caesar for clarity between the two) as he focused only on Nearctic blowflies. The remaining species that would fall into this clade based on his diagnostic criteria grouped with L. caesar and L. illustris in our analyses (Fig. 4), and includes species that are primary and secondary facultative parasites as well as species that are saprophagous.

Bufolucilia Townsend, 1919 (type species: Lucilia bufonivora) includes the species bufonivora, silvarum and (by monophyly) elongata, which are found in Europe and North America. Bufolucilia forms a part of the clade that includes most of the facultatively parasitic Lucilia species (Fig. 4). There is no obvious reason to separate Lucilia into (sub)genera based on the parasitic behaviour of the species because primary and secondary facultatively parasitic and saprophagous species are spread throughout the genus (Fig. 4). Recognising Bufolucilia also makes Phaenicia paraphyletic (Fig. 4).

Phumonesia Villeneuve, 1914 and Roubaudiella Séguy, 1925 (type species: Phumonesia infernalis Villeneuve, 1914 = Roubaudiella caerulea Robineau-Desvoidy, 1863) are monotypic genera founded on the same species, and therefore objective synonyms. The only species shows affinities with Hemipyrellia in some analyses (Fig. 2, 4), and is always embedded inside Lucilia, leaving no reason to recognise a separate genus.

Similarly, Francilia Shannon, 1924, and Acrophagella Ringdahl, 1942, are objective synonyms because they are based on the same species. Several other genus-group 
taxa have been erected within the Luciliinae, including Caesariceps Rodendorf, 1926, Dasylucilia Rodendorf, 1926, Luciliella Malloch, 1926 and Viridinsula Shannon, 1926. Their status needs assessment, and the results presented here suggest that morphological analyses alone will not be sufficient. Phylogenetic studies including a selection of both nuclear and mitochondrial genes are recommended.

Hemipyrellia Townsend, 1918 (type species: Lucilia fernandica Macquart, 1855) was erected as a genus by Townsend (1918) and revised by Aubertin (1931). It had previously been suggested that Hemipyrellia was a synonym of Lucilia (Shannon 1926). Hemipyrellia is restricted to the Old World and the species are saprophagous. The results of this study place Hemipyrellia within Lucilia for both nuclear and mitochondrial analyses with 100\% support (Figs 1 and 2), the COI barcode Bayesian tree (Fig. 5) with very strong support, and the morphological majority rule consensus tree (Fig. 6) with weak (56\%) support.

In two studies of Australian blowflies, Hemipyrellia was found to be a sister-group to Lucilia (Wallman et al. 2005, Nelson et al. 2012), but these studies included only species of Lucilia that occur in Australia, thus Hemipyrellia may be a sister-clade to Australian Lucilia as an artefact of taxon sampling. Similarly, another study (Singh and Wells 2013) found Hemipyrellia to be sister-group to Lucilia, but this was based on one specimen of Lucilia sericata and one specimen of Hemipyrellia fernandica. Several other studies have sequenced Hemipyrellia specimens and found them to lie within Lucilia (Wells et al. 2007, Park et al. 2009, Liu et al. 2011, McDonagh and Stevens 2011). Two specimens of $H$. ligurriens from Taiwan (Fig. 2) group within the $L$. cuprina clade. This is probably a misidentification because the specimens of $H$. ligurriens and $H$. pulchra, both from China, group with $H$. fernandica sequenced in this study. Assuming that the other Hemipyrellia specimens are not all misidentified, these previous studies together with the results of this study provide strong support for the synonymy of Hemipyrellia and Lucilia.

Dyscritomyia Grimshaw, 1901 (type species: Prosthetochaeta robusta Grimshaw, 1901) contains 35 nominal species that are all found exclusively on the Hawaiian Islands (James 1981). The biology of Dyscritomyia differs from the other Luciliinae in that at least some species are viviparous and produce only one larva at a time that is retained in the uterus for the first two instar stages. Little is known about their parasitic behaviour but it is assumed that Dyscritomyia species are facultatively parasitic saprophages (Hardy 1981). Dyscritomyia was included in the COI Bayesian inference analysis and was recovered as a separate clade to Lucilia (Fig. 2). In previous studies, Dyscritomyia was recovered within Lucilia when analysing the COI and EF-1a genes (Wells et al. 2007, McDonagh and Stevens 2001) but it was recovered as a sister clade to Lucilia when analysing the $28 S$ gene (McDonagh and Stevens 2011). Dyscritomyia was also recovered as a sister group to Lucilia in a study of the COI and COII genes (Wells et al. 2002). The current study used only a 576 bp region of the total COI gene from the sequences available on GenBank that were used in the study of Wells et al. (2002), but still recovered Dyscritomyia as a sister clade to Lucilia. It therefore does not appear that the length of the COI sequence affects the analysis significantly. 
This study used 20 species of Lucilia in the COI analysis while the previous studies used six and 13 species, respectively (Wells et al. 2002, McDonagh and Stevens 2011). The position of Dyscritomyia relative to Lucilia may be determined by the taxon sampling of Lucilia, as mentioned regarding Hemipyrellia. This highlights the need for a more comprehensive study of this genus and inclusion of as many Dyscritomyia and Lucilia species as possible to confirm the taxonomic relationship between Dyscritomyia and Lucilia.

Hypopygiopsis Townsend, 1916 (type species: Hypopygiopsis splendens Townsend, 1916 = Hypopygiopsis fumipennis Walker, 1856) is restricted to the Asian and Australasian regions of the world (Kurahashi 1977). This genus apparently exhibits both oviparous and larviparous behaviour. The larval behaviour includes both facultative parasitism and saprophagy. Hypopygiopsis was included in the Bayesian inference analysis of the COI barcode dataset. One Hypopygiopsis infumata sequence grouped within Lucilia (Fig. 5) as part of a clade including L. hainanensis + L. papuensis + L. bazini. On closer examination of the sequences, Hypopygiopsis infumata was identical to the Lucilia bazini sequence from China. The L. hainanensis sequence from China that groups with these two sequences differs by only one base pair. This places doubt on the identification of these sequences and prevents any meaningful inferences being drawn. The second Hypopygiopsis infumata sequence groups with Hemipyrellia. There are only five sequences of Hypopygiopsis publically available and therefore the limited number of sequences constrains the credibility of this result and it is recommended that more sequences of this genus are examined to clarify if this genus should also be synonymised with Lucilia.

\section{Conclusion}

Lucilia sericata and L. cuprina are indeed sister-species. Lucilia mexicana is confirmed to be paraphyletic with respect to L. coeruleiviridis, possibly as a result of hybridisation and introgression. Lucilia caesar and L. illustris are both paraphyletic and further studies with different genes are needed to determine if these two species can be identified using molecular methods. Hemipyrellia should be synonymised with Lucilia because this genus sits within Lucilia in all of the analyses conducted in this study. Dyscritomyia requires further studies to confirm its phylogenetic positioning with regard to Lucilia because taxon sampling appears to have an impact on the analysis. The limited number of sequences available for Hypopygiopsis and the apparent misidentification of sequences prevent any conclusions being drawn about its relationship to Lucilia. In this study we have identified at least three cases of misidentified sequences from GenBank, which is a well-known problem (Bridge et al. 2003, Harris 2003, Nilsson et al. 2006, Valkiūnas et al. 2008). There is no geographic pattern to the distribution of the different parasitic behaviours within the Luciliinae and no reason to sub-divide Lucilia into genera or sub-genera based on either geographic location or parasitic behaviour. 


\section{Acknowledgments}

We thank Dave Emery, Georg Goergen, Chris Kelly, Ashley Kirk-Spriggs, Nicky Lunt, Rich Merritt, Hideharu Numata, Cameron Richards, Kiyoshi Saigusa, Kabkaew Sukontason, Robyn Tourle, James Wallman, Terry Whitworth and Claude Wyss for providing us with specimens. Funding was provided by the National Research Foundation (NRF) of South Africa. Any opinion, findings and conclusions or recommendations expressed in this material are those of the author and do not necessarily reflect the views of the National Research Foundation.

\section{References}

Ash N, Greenberg B (1975) Developmental temperature responses of the sibling species Phaenicia sericata and Phaenicia pallescens. Annals of the Entomological Society of America 68: 197-200. doi: 10.1093/aesa/68.2.197

Aubertin D (1931) Revision of the genus Hemipyrellia Tns. (Diptera, Calliphoridae). Proceedings of the Zoological Society of London, 497-509. doi: 10.1111/j.1096-3642.1931. tb01026.x

Aubertin D (1933) Revision of the genus Lucilia R.-D. (Diptera, Calliphoridae). Linnean Society Journal of Zoology 38: 389-463. doi: 10.1111/j.1096-3642.1933.tb00991.x

Bishop DM (1991) Variations in numbers of occipital setae for two species of Lucilia (Diptera: Calliphoridae) in New Zealand. New Zealand Entomologist 14: 28-31. doi: 10.1080/00779962.1991.9722609

Bishop DM (1995) Subspecies of the Australian green blowfly (Lucilia cuprina) recorded in New Zealand. New Zealand Veterinary Journal 43: 164-165. doi: 10.1080/00480169.1995 .35880

Boehme P, Amendt J, Zehner R (2012) The use of COI barcodes for molecular identification of forensically important fly species in Germany. Parasitology Research 110: 2325-2332. doi: $10.1007 /$ s00436-011-2767-8

Bridge PD, Spooner BM, Roberts PJ, Panchal G (2003) On the unreliability of published DNA sequences. New Phytologist 160: 43-48. doi: 10.1046/j.1469-8137.2003.00861.x

Byrd JH, Castner JL (2010) Forensic Entomology: The utility of arthropods in legal investigations. CRC Press, Taylor \& Francis Group, Boca Raton, 681 pp.

Chen W-Y, Hung T-S, Shiao S-F (2004) Molecular identification of forensically important blow fly species (Diptera: Calliphoridae) in Taiwan. Journal of Medical Entomology 41: 47-57. doi: 10.1603/0022-2585-41.1.47

DeBry R, Timm AE, Dahlem GA, Stamper T (2010) mtDNA-based identification of Lucilia cuprina (Wiedemann) and Lucilia sericata (Meigen) (Diptera: Calliphoridae) in the continental United States. Forensic Science International 202: 102-109. doi: 10.1016/j. forsciint.2010.04.038

DeBry R, Timm AE, Wong ES, Stamper T, Cookman C, Dahlem GA (2012) DNA-Based identification of forensically important Lucilia (Diptera: Calliphoridae) in the conti- 
nental United States. Journal of Forensic Sciences 58: 73-78. doi: 10.1111/j.15564029.2012.02176.x

Farris JS, Kallerjo M, Kluge AG, Bult C (1994) Testing significance of congruence. Cladistics 10: 315-319. doi: 10.1111/j.1096-0031.1994.tb00181.x

Fischer OA (2000) Blowflies of the genera Calliphora, Lucilia and Protophormia (Diptera, Calliphoridae) in South-Moravian urban and rural areas with respect to Lucilia bufonivora Moniez, 1876. Acta Veterinaria Brno 69: 225-231. doi: 10.2754/avb200069030225

GilArriortua M, Salona Bordas MI, Caine LM, Pinheiro F, de Pancorbo MM (2013) Cytochrome $\mathrm{b}$ as a useful tool for the identification of blowflies of forensic interest (Diptera, Calliphoridae). Forensic Science International 228: 132-136. doi: 10.1016/j.forsciint.2013.02.037

Hall DG (1948) The blowflies of North America. Thomas Say Foundation, Washington DC.

Hall TA (1999) BioEdit: a user-friendly biological sequence alignment editor and analysis program for Windows 95/98/NT. Nucleic Acids Symposium Series 41: 95-98.

Hardy DE (1981) Insects of Hawaii. Vol 14. Diptera: Cyclorrhapha IV. Series Schizophora Section Calypteratae. University Press of Hawaii, Honolulu.

Harris DJ (2003) Can you bank on GenBank? Trends in Ecology and Evolution 18: 317-319. doi: 10.1016/S0169-5347(03)00150-2

Harvey ML, Dadour IR, Gaudieri S (2003) Mitochondrial DNA cytochrome oxidase I gene: potential for distinction between immature stages of some forensically important fly species (Diptera) in Western Australia. Forensic Science International 131: 134-139. doi: 10.1016/ S0379-0738(02)00431-0

Harvey ML, Mansell MW, Villet MH, Dadour IR (2003) Molecular identification of some forensically important blowflies of southern Africa and Australia. Medical and Veterinary Entomology 17: 363-369. doi: 10.1111/j.1365-2915.2003.00452.x

Harvey ML, Gaudieri S, Villet MH, Dadour IR (2008) A global study of forensically significant calliphorids: Implications for identification. Forensic Science International 177: 66-76. doi: 10.1016/j.forsciint.2007.10.009

Heath ACG, Bishop DM (2006) Flystrike in New Zealand: An overview based on a 16-year study, following the introduction and dispersal of the Australian sheep blowfly, Lucilia cuprina Wiedemann (Diptera: Calliphoridae). Veterinary Parasitology 137: 333-344. doi: 10.1016/j.vetpar.2006.01.006

Hepburn GA (1943) Sheep blowfly research I - A survey of maggot collections from live sheep and a note on the trapping of blowflies. Onderstepoort Journal of Veterinary Science and Animal Industry 18: 13-18.

Holloway BA (1991) Morphological characters to identify adult Lucilia sericata (Meigen, 1826) and L. cuprina (Wiedemann, 1830) (Diptera: Calliphoridae). New Zealand Journal of Zoology 18: 415-420. doi: 10.1080/03014223.1991.10422847

Huelsenbeck JP, Ronquist F (2001) MRBAYES: Bayesian inference of phylogenetic trees. Bioinformatics 17: 754-755. doi: 10.1093/bioinformatics/17.8.754

Huson DH, Bryant D (2006) Application of phylogenetic networks in evolutionary studies. Molecular Biology and Evolution 23: 254-267. doi: 10.1093/molbev/msj030

James MT (1971) New species and records of Australasian Calliphorinae, with special reference to the fauna of new guinea (Diptera: Calliphoridae). Pacific Insects 13: 1-12. 
James MT (1981) Genus Dyscritomyia Grimshaw. In: Hardy DE. A Manual of the Insects of the Hawaiian Islands, including an Ennumeration of the Species and Notes on the Origin, Distribution, Hosts, Parasites, etc. The University Press of Hawaii, Honolulu, Vol. 14: 294-349.

Jordaens K, Sonet G, Richet R, Dupont E, Braet Y, Desmyeter S (2013) Identification of forensically important Sacrcophaga species (Diptera: Sarcophagidae) using the mitochondrial COI gene. International Journal of Legla Medicine 127: 491-504. doi: 10.1007/s00414012-0767-6

Kurahashi H (1977) The tribe Luciliini from Australian and Oriental regions I. Genus Hypopygiopsis Townsend (Diptera, Calliphoridae). The Entomological Society of Japan 45: 553-562.

Liu Q-L, Cai J-F, Chang Y-F, Gu Y, Guo Y-D, Wang X-H, Weng J.-F, Zhong M, Wang X, Yang L, Wu K-L, Lan L-M, Wang J-F, Chen Y-Q (2011) Identification of forensically important blow fly species (Diptera: Calliphoridae) in China by mitochondrial cytochrome oxidase I gene differentiation. Insect Science 18: 554-564. doi: 10.1111/j.17447917.2010.01377.x

Malloch JR (1926) Exotic Muscaridae (Diptera). Annals and Magazine of Natural History 17: 489-510. doi: 10.1080/00222932608633438

Marinho MAT, Junqueira ACM, Paulo DF, Esposito MC, Villet MH, Azeredo-Espin AML (2012) Molecular phylogenetics of Oestroidea (Diptera: Calyptratae) with emphasis on Calliphoridae: insights into the inter-familial relationships and additional evidence for paraphyly among blowflies. Molecular Phylogenetics and Evolution 65: 840-854. doi: 10.1016/j.ympev.2012.08.007

McDonagh LM, Stevens JR (2011) The molecular systematics of blowflies and screwworm flies (Diptera: Calliphoridae) using 28S rRNA, COX1 and EF-1 $\alpha$ : insights into the evolution of dipteran parasitism. Parasitology 138: 1760-177. doi: 10.1017/S0031182011001089

Nelson LA, Wallman JF, Dowton M (2007) Using COI barcodes to identify forensically and medically important blowflies. Medical and Veterinary Entomology 21: 44-52. doi: 10.1111/j.1365-2915.2007.00664.x

Nelson LA, Lambkin CL, Batterham P, Wallman JF, Dowton M, Whiting MF, Yeates DK, Cameron SL (2012) Beyond barcoding: A mitochondrial genomics approach to molecular phylogenetics and diagnostics of blowflies (Diptera: Calliphoridae). Gene 511: 131-142. doi: 10.1016/j.gene.2012.09.103

Nilsson RH, Ryberg M, Kristiansson E, Abarenkov K, Larsson K-H, et al. (2006) Taxonomic Reliability of DNA Sequences in public sequence databases: a fungal perspective. PLoS ONE 1(1): e59. doi: 10.1371/journal.pone.0000059

Marinho MAT, Junqueira ACM, Paulo DF, Esposito MC, Villet MH, Azeredo-Espin AML (2012) Molecular phylogenetics of Oestroidea (Diptera: Calyptratae) with emphasis on Calliphoridae: insights into the inter-familial relationships and additional evidence for paraphyly among blowflies. Molecular Phylogenetics and Evolution 65: 840-854. doi: 10.1016/j.ympev.2012.08.007

McDonagh LM, Stevens JR (2011) The molecular systematics of blowflies and screwworm flies (Diptera: Calliphoridae) using 28S rRNA, COX1 and EF-1 $\alpha$ : insights into the evolution of dipteran parasitism. Parasitology 138: 1760-177. doi: 10.1017/S0031182011001089 
Nelson LA, Wallman JF, Dowton M (2007) Using COI barcodes to identify forensically and medically important blowflies. Medical and Veterinary Entomology 21: 44-52. doi: 10.1111/j.1365-2915.2007.00664.x

Nelson LA, Lambkin CL, Batterham P, Wallman JF, Dowton M, Whiting MF, Yeates DK, Cameron SL (2012) Beyond barcoding: A mitochondrial genomics approach to molecular phylogenetics and diagnostics of blowflies (Diptera: Calliphoridae). Gene 511: 131-142. doi: 10.1016/j.gene.2012.09.103

Nilsson RH, Ryberg M, Kristiansson E, Abarenkov K, Larsson K-H, et al. (2006) Taxonomic Reliability of DNA Sequences in public sequence databases: a fungal perspective. PLoS ONE 1(1): e59. doi: 10.1371/journal.pone.0000059

Reibe S, Schmitz J, Madea B (2009) Molecular identification of forensically important blowfly species (Diptera: Calliphoridae) from Germany. Parasitology Research 106: 257-261. doi: 10.1007/s00436-009-1657-9

Roe AD, Sperling FAH (2007) Patterns of evolution of mitochondrial cytochrome c oxidase I and II DNA and implications for DNA barcoding. Molecular Phylogenetics and Evolution 44: 325-345. doi: 10.1016/j.ympev.2006.12.005

Rognes K (1980) The blow-fly genus Lucilia Robineau-Desvoidy (Diptera, Calliphoridae) in Norway. Fauna norvegica Series B 27: 39-52.

Rognes K (1991) Blowflies (Diptera, Calliphoridae) of Fennoscandia and Denmark. Fauna Enomogolica Scandanavia 245: 1-277.

Rognes K (1994) First record of the sheep greenbottle fly Lucilia cuprina (Wiedemann, 1830) from Europe (Diptera: Calliphoridae) with additional Spanish records of Calliphoridae, Muscidae and Sarcophagidae. Eos 69: 41-44

Rubinoff D, Cameron S, Will K (2006) A genomic perspective on the shortcomings of mitochondrial DNA for "barcoding" identification. Journal of Heredity 97: 581-594. doi: $10.1093 /$ jhered/es1036

Shannon RC (1926) Synopsis of the American Calliphoridae (Diptera). Proceedings of the Entomological Society of America 28: 115-133.

Simon C, Buckley RT, Frati F, Stewart JB, Beckenbach AT (2006) Incorporating molecular evolution into phylogenetic analysis, and a new compilation of conserved polymerase chain reaction primers for animal mitochondrial DNA. Annual Review of Ecological Evolutionary Systematics 37: 545-579. doi: 10.1146/annurev.ecolsys.37.091305.110018

Singh B, Wells JD (2013) Molecular systematics of the Calliphoridae (Diptera: Oestroidea): Evidence from one mitochondrial and three nuclear genes. Journal of Medical Entomology 50(1): 15-23. doi: 10.1603/ME11288

Smith KE (1986) A manual of forensic entomology. British National History Museum, London, 205 pp.

Sonet G, Jordaens K, Braet Y, Desmyter S (2012) Why is the molecular identification of the forensically important blowfly species Lucilia caesar and L. illustris (family Calliphoridae) so problematic? Forensic Science International 223: 153-159. doi: 10.1016/j.forsciint.2012.08.020

Sonet G, Jordaens K, Braet Y, Bourguignon L, Dupont E, Backeljau T, De Meyer M, Desmyter S (2013) Utility of GenBank and the Barcode of Life Data Systems (BOLD) for the 
identification of forensically important Diptera from Belgium and France. ZooKeys 365: 307-328. doi: 10.3897/zookeys.365.6027

Stevens J, Wall R (1996) Classification of the genus Lucilia (Diptera: Calliphoridae): a preliminary parsimony analysis. Journal of Natural History 30: 1087-1094. doi: 10.1080/00222939600770581

Stevens J, Wall R (1997) The evolution of ectoparasitism in the genus Lucilia (Diptera: Calliphoridae). International Journal for Parasitology 27: 51-59. doi: 10.1016/S00207519(96)00155-5

Stevens J, Wall R (2001) Genetic relationships between blowflies (Calliphoridae) of forensic importance. Forensic Science International 120: 116-123. doi: 10.1016/S0379-0738(01)00417-0

Stevens JR, Wall R, Wells JD (2002) Paraphyly in Hawaiian hybrid blowfly populations and the evolutionary history of anthropophilic species. Insect Molecular Biology 11: 141-148. doi: 10.1046/j.1365-2583.2002.00318.x

Stevens JR (2003) The evolution of myiasis in blowflies (Calliphoridae). International Journal for Parasitology 33: 1105-1113. doi: 10.1016/S0020-7519(03)00136-X

Stevens JR, Wallman JF (2006) The evolution of myiasis in humans and other animals in the Old and New Worlds (part I): phylogenetic analyses. Trends in Parisitology 22: 129-136. doi: 10.1016/j.pt.2006.01.008

Stevens JR, Wallman JF, Otranto D, Wall R, Pape T (2006) The evolution of myiasis in humans and other animals in the Old and New Worlds (part II): biological and life-history studies. Trends in Parisitology 22: 181-188. doi: 10.1016/j.pt.2006.02.010

Swofford DL (2003) PAUP* Phylogenetic Analysis Using Parsimony (*and Other Methods), Version 4. Sinauer Associates, Sunderland, MA.

Tantawi TI, Williams KA, Villet MH (2010) An Accidental but safe and effective use of Lucilia cuprina (Diptera: Calliphoridae) in maggot debridement therapy in Alexandria, Egypt. Journal of Medical Entomology 47: 491-494. doi: 10.1093/jmedent/47.3.491

Tourle R, Downie DA, Villet MH (2009) A morphological and molecular comparison of Lucilia cuprina and L. sericata (Diptera: Calliphoridae) in South Africa. Medical and Veterinary Entomology 23: 6-14. doi: 10.1111/j.1365-2915.2008.00765.x

Ullyett GC (1945) Species of Lucilia attacking sheep in South Africa. Nature 155: 636-637. doi: $10.1038 / 155636 b 0$

Van Nieukerken EJ, Doorenweerd C, Stokvis FR, Groenenberg DSJ (2012) DNA barcoding of the leaf-mining moth subgenus Ectoedemia s. str. (Lepidoptera: Nepticulidae) with COI and EF$1 \alpha$ : two are better than one in recognizing cryptic species. Contributions to Zoology 81: 1-24.

Valkiūnas G, Atkinson CT, Bensch S, Sehgal RNM, Ricklefs R (2008) Parasite misidentifications in GenBank: how to minimize their number? Trends in Parasitology 24: 247-248. doi: $10.1016 /$ j.pt.2008.03.004

Vogt WG, Woodburn TL (1979) Ecology, distribution and importance of sheep myiasis flies in Australia. National Symposium of the sheep blowfly and flystrike in sheep. N.S.W. Ag. Sydney.

Wallman JF, Leys R, Hogendoorn K (2005) Molecular systematics of Australian carrion-breeding blowflies (Diptera: Calliphoridae) based on mitochondrial DNA. Invertebrate Systematics 19: 1-15. doi: 10.1071/IS04023 
Waterhouse DF, Paramonov SJ (1950) The status of the two species of Lucilia (Diptera, Calliphoridae) attacking sheep in Australia. Australian Journal of Scientific Research 3: 310-336.

Wells JD, Goff ML, Tomberlin K (2002) Molecular systematics of the endemic Hawaiian blowfly genus Dyscritomyia Grimshaw (Diptera: Calliphoridae). Medical Entomology and Zoology 53: 231-238.

Wells JD, Wall R, Stevens JR (2007) Phylogenetic analysis of forensically important Lucilia flies based on cytochrome oxidase I sequence: a cautionary tale for forensic species determination. International Journal of Legal Medicine 121: 229-233. doi: 10.1007/s00414006-0147-1

Whitworth T (2006) Keys to the genera and species of blow flies (Diptera: Calliphoridae) of America north of Mexico. Proceedings of the Entomological Society of Washington 108: $689-725$.

Whitworth T (2010) Keys to the genera and species of blow flies (Diptera: Calliphoridae) of the West Indies and description of a new species of Lucilia Robineau-Desvoidy. Zootaxa 2663: 1-35.

Whitworth TL, Dawson RD, Magalon H, Baudry E (2007) DNA barcoding cannot reliably identify species of the blowfly genus Protocalliphora (Diptera: Calliphoridae). Proceedings of the Royal Society B 274: 1731-1739. doi: 10.1098/rspb.2007.0062

Williams KA, Cronje FJ, Avenant L, Villet MH (2008) Identifying flies used for maggot debridement therapy. South African Medical Journal 98: 196-197.

Williams KA, Villet MH (2013) Ancient and modern hybridization between Lucilia sericata and L. cuprina (Diptera: Calliphoridae). European Journal of Entomology 110: 187-196. doi: 10.14411/eje.2013.029

Zumpt FKE (1965) Myiasis in man and animals in the old world: a textbook for physicians, veterinarians and zoologists. Butterworths, London, 277 pp. 